\title{
Different functions, different histories. Modal particles and discourse markers from a diachronic point of view*
}

\section{Richard Waltereit}

Newcastle University. School of Modern Languages

Old Library Building

Newcastle NE1 7RU, United Kingdom

richard.waltereit@newcastle.ac.uk

\section{Ulrich Detges}

University of Munich. Institut für Romanische Philologie

Ludwigstrasse 25. 80539 München, Germany

ulrich.detges@romanistik.uni-muenchen.de

\begin{abstract}
One of the main concerns of recent research in discourse markers, modal particles and related elements has been the problem of a neat categorical delimitation between the major classes involved. Comparing the Spanish discourse particle bien and its French cognate modal particle bien, we show that the functional difference between discourse markers and modal particles can be accounted for in diachronic terms. In other words, discourse markers and modal particles arise in different diachronic pathways, and ultimately from different pragmatic strategies. Strategies which eventually yield discourse markers are related to the joint coordination of human interaction. In contrast, strategies which give rise to modal particles make reference to the status of a given proposition for the ensuing discourse. Our results suggest that there are levels of generalization on semantic change below the overarching tendencies of subjectification (Traugott and Dasher 2002). More importantly, we provide specific motivations for these levels of generalization, and ultimately for subjectification itself.
\end{abstract}

Key words: discourse markers, modal particles, grammaticalization, subjectification, bien, Spanish, French.

\section{Table of Contents}

0 . Introduction

1. The synchronic view: discourse markers vs. modal particles

2. The rise of discourse markers
3. French bien - the rise of a modal particle

4. Conclusion

References

* We would like to thank Elizabeth Closs Traugott for her careful reading of this article and for her insightful comments and suggestions. 


\section{Introduction}

Recent years have seen an increasing interest in all sorts of pragmatic markers, such as discourse markers and modal particles. One of the main concerns of research in this field has been the problem of a neat categorical delimitation between the major classes involved. In this paper, we want to approach this question from a new angle. We will show that the functional difference between discourse markers and modal particles can be accounted for in diachronic terms. In other words, discourse markers and modal particles arise in different diachronic pathways, and ultimately from different characteristic pragmatic strategies. Concomitantly, our results suggest that there are levels of generalization on semantic change below the overarching tendencies of subjectification (Traugott and Dasher 2002). More importantly, we provide very specific motivations for these levels of generalization, and ultimately for subjectification itself.

\section{The synchronic view: discourse markers vs. modal particles}

As a first step, let us take a glance at the functional difference between discourse markers and modal particles from a synchronic perspective. Recurrent cases in point are elements which are derived from adverbs meaning 'well'. Thus, Spanish has a discourse marker bien, derived from adverbial bien 'well' as in example (1).

\section{(1) Adverbial bien in Spanish (Corpus Oral 1992)}

[E]n verano, julio, septiembre y octubre el gradiente térmico está bien formado.

'In summer, July, September and October, the thermal gradient is well-formed.'

As a discourse marker, Sp. bien often occurs turn-initially, as in (2) (cf. Serrano 1999).

(2) Spanish bien as a discourse marker (Corpus oral 1992)

$<$ S1 $>$ El derecho a que todo ciudadano [...], por muy grave que fuera el hecho, tiene derecho a esa legítima defensa.

'The right which every citizen, however serious the deed may have been, he has a right to this self-defense.'

$<$ S2> Bien. Eh... creo que hubo un tema que no quedó demasiado claro y me gustaría... repetirlo antes de la próxima consulta.

'Well, eh... I think there was an issue which was not too clear, and I would like ... to repeat it before the next consultation.'

Here, bien does not signal approval of the previous speaker's argumentation. Rather, it serves to close a topic addressed in the foregoing contribution. At the same time, it is used to introduce a new topic. This is an example of what is commonly acknowledged as the function typical of discourse markers: they overtly indicate the relationship of a given chunk of discourse/text to a wider stretch of 
the same discourse/text. Put more generally, they concern the structure or form of discourse, independent of its content, whether illocutionary or propositional. The scope of discourse markers is extremely variable: what exactly is a "chunk of discourse" is determined on purely discourse-structural grounds. In particular, the discourse units referred to by such markers are not necessarily identical with grammatical units at the sentence-constituent level. This in turn means that the placement of discourse markers is not subject to constraints of grammatical nature.

Unlike Spanish bien, French bien (see (3)) can be used as a modal particle (see (4)).

(3) Adverbial bien in French (Hansen 1998b)

Ce roman est bien écrit.

'This novel is well written.'

(4) French bien as a modal particle

Vous avez bien reçu mon message?

you have bien received my message

'You did receive my message, didn't you?'

As a modal particle, Fr. bien is, among other things, employed in yes/no-questions, where it indicates that the speaker expects an affirmative answer rather than a negative one. In (4), bien is restricted to the position following the finite verb.

As is illustrated in this yes/no-question, modal particles function at the speechact level. Put differently, they are sensitive to illocutionary content. More precisely, they are conventionally tied to particular speech-act types. While discourse markers signal the formal structure of textual organization, independent of particular contents, modal particles are highly content-dependent and have a scope which is conventionally fixed (see Autenrieth 2002). For this reason, they are subject to heavy syntactic restrictions.

The preceding discussion is summarized in (5) for convenience.

\section{Discourse markers}

function at discourse level variable scope

variable syntactic position

\section{Modal particles}

function at speech-act level

fixed scope

fixed syntactic position

French bien is an adverb and a modal particle. Casual observation suggests that it furthermore may be used as a discourse marker. However we are not aware of research on this. ${ }^{1}$ Spanish bien, on the contrary is an adverb and a discourse marker. Their German and English cognates, gut and well, pattern with Spanish:

1. French has two other discourse markers, bon and ben, of which bon in particular shares certain features with Spanish bien and bueno. Ben is sometimes considered a phonologically eroded variant 
(6) Discourse markers and modal particles based on adverb 'well'

$\begin{array}{llll} & \text { adverb } & \text { discourse marker } & \text { modal particle } \\ \text { French } & \text { bien } & \text { bien } & \text { bien } \\ \text { Spanish } & \text { bien } & \text { bien } & - \\ \text { German } & \text { gut } & \text { gut } & - \\ \text { English } & \text { well } & \text { well } & -\end{array}$

This comparison calls for two observations: First, it appears that cross-linguistically, discourse markers are much more common than modal particles. In fact, discourse markers are often reported as near-universal, whereas modal particles as a word class are highly language-specific (even though their function is arguably universal, too, see Waltereit 2001). ${ }^{2}$

Second, a semantic analysis in terms of a single underlying meaning (a Gesamtbedeutung) for the different readings in each language is highly implausible. According to proponents of such analyses (cf. e.g. Autenrieth 2002, Wegener 2002 for German modal particles), the non-propositional uses (i.e. the discoursemarker function and the function of the modal particle) are contextually specified instantiations of adverbial 'well'. If this was really the case, we would expect all languages with an adverb meaning 'well' to have developed identical nonpropositional uses for this item, since adequate contexts are always available. But the language-specific nature of the discourse-marker function and the modalparticle usage suggests that both have conventional status, which means that they have been brought about independently by language change. The existence of stable contrasts between languages with respect to the availability of pragmatic markers means that these are unlikely to be derived from an underlying common meaning, as the Gesamtbedeutungs-analysis would suggest. Nevertheless, the Gesamtbedeutungs-analysis draws upon an important insight: there are intuitively palpable semantic relations between the adverb and the respective non-propositional use. A more suitable model which captures both the conventional character of the different meanings and the semantic relations that hold between them is polysemy (Hansen 1998a, Waltereit 2006). As is customary in research on lexical semantic change, we assume that the synchronic relations between the meanings of polysemous items are reminiscent of the diachronic semantic changes by which they have been brought about. Put more simply, polysemy is a synchronic reflex of language change. Hence, if the mechanisms of contextual specification as assumed by Gesamtbedeutungs-approaches have any real existence, it will be in diachronic change rather than in synchronic function. Therefore, a

of bien (Dostie 2004). As its function is highly specific in Modern Standard French (see Hansen 1995, 1998a), there is no functional overlap with the adverb bien. Therefore we do not consider ben a variant of adverbial bien.

2. It should not be inferred from (6) that French is the only language with modal particles. In fact, bien is one of the very few modal particles of that language. Conversely, German and the other continental Germanic languages do have rich inventories of modal particles (e.g. German ja, doch, eben, halt, eigentlich etc.). See Fernández-Villanueva, this volume. 
closer look at the genesis of discourse markers and modal particles will prove insightful.

\section{The rise of discourse markers}

In this section we would like to focus on Spanish bien. Before setting out the diachronic analysis, we are going to address its function in contemporary Spanish in a more detailed fashion.

In the literature, bien is often treated together with its near-synonym bueno (see Martín Zorraquino and Portolés 1999, Garcés Gómez 1996). Both items have in common that they are used at places where the coherence of the discourse is at risk.

Example (2) may serve as an illustration. In (2) the speaker closes off a topic addressed by the previous speaker and begins a new one. Thus, coherence is jeopardized by a brusque change of topic. Crucially, bien signals that this switch takes place in a maximally cooperative fashion. In the literature, bien and bueno have been characterized as devices for "negotiating" coherence (cf. Serrano 1999: 121).

Moreover, bien and bueno are used when the speaker disagrees with the previous speaker, thereby giving the unfolding discourse an unexpected turn (and potentially putting at risk its coherence):

(7) Bien as a marker of disagreement (Corpus Oral 1992)

$<$ S1> ¿Te vas a presentar al Conservatorio [...]? ¿Cuándo?

'You are going to present yourself at the conservatorium? When?'

$<$ S2> Cuando me examine.

When they will examine me.'

$<$ S1 $>$ Bien, no. Te tienes que presentar antes de examinarte para que después te puedas examinar.

'Well, no. You have to present yourself before the exam so that afterwards you can be examined.'

$<$ S2> Bueno, pues no sé.

'Well, I don't know.'

Note that once again bien ensures a maximally cooperative exchange. S1's "no" is not entirely appropriate, given that it normally requires a preceding yes-no question. Instead, S1 fills in the discourse marker bien, thereby repairing this potential coherence gap. ${ }^{3}$

A third context type in which bien and bueno often appear are answers. This is the case when the incipient answer is in some way inconsistent with the presuppositions of the preceding question:

3. This analysis is in line with Hansen's (1995, 1998a) account of French bon. According to her, bon is prototypically used to override the effect of some "undesirable" element in discourse or in the situation. This notion covers all sorts of phenomena, including risks for discourse coherence. 
(8) Bueno in answers (Fuentes Rodríguez 1998: 55)

A: ¿Dónde nacieron tus padres?

'Where were your parents born?'

B: Bueno, mi padre en San Julián y mi madre en La Macarena.

'Well, my father in San Julián and my mother in La Macarena.'

The plural in the question suggests that A expects B's parents to have been born in the same place. However, bueno makes it clear that this expectation is not going to be met in the ensuing answer.

Whereas bueno may be used to repair all kinds of mismatches between question and answer, bien appears to be specialized in a single type of inconsistency: it is used when the projected answer will require considerably more effort than the question seems to suggest (Garcés Gómez 1996: 131). ${ }^{4}$ Thus, bien in (9) indicates that the speaker is going to launch into a lengthy lecture, which finally will turn out to be approximately 200 words long (and which, therefore, we will not reproduce entirely).

(9) Bien in answers (Corpus Oral 1992)

$<$ S1 $>$ ¿Y dónde, nos puedes informar, donde eh... puede uno documentarse, perfeccionar esas actitudes para presentarse mejor, de cara a un empleo? 'And where, can you tell us, where eh.. one can get information, work on these attitudes to present oneself better, in view of a job [offer]?'

$<$ S2> Bien. Hay... diferentes lugares y yo creo que con el tiempo, poco a poco van a ir aumentando en número y diversi<palabra cortada $>\ldots$ diversificándose la oferta. < vacilación $>$ En primer lugar, y... históricamente, eh... la primera institución que ha ofertado cursos de entrenamiento en técnicas de búsqueda de empleo ha sido el INEM, el Instituto Nacional de Empleo. [...]

'Well. There are several places and I believe that with time, little by little, they will keep rising in number and the offer will get more diversified. In the first place, and historically, the first institution to have offered training courses in job searching techniques has been the INEM, the National Institute of Employment.

The question-answer pairs exemplify best how bien and bueno are used in the negotiation of coherence. On the one hand, the answering speaker explicitly accepts and ratifies the question addressed to her. On the other hand, however, she does not provide an answer of the type projected in the question: either certain presuppositions of the question are not accepted (cf. (8)), or the answer is more complex than projected in the question (cf. (9)). In both of the above examples, the speaker might as well refute the question or reformulate it in order to

4. We do not imply by this that bien occurs in answers only. However if bien occurs in answers then it indicates that this answer will require more effort than the question seems to suggest. 
express her disagreement with certain expectations contained in it. Even though maximally informative and coherent, the latter alternative would be very costly in terms of encoding effort and it might hamper the smooth progress of the exchange. Instead, the speaker using bien or bueno signals that she tacitly modifies the communicative task assigned to her by the previous question. A third, even less costly alternative would be to not express at all one's disagreement with the question and to provide straight away an answer which is judged most adequate to the interests expressed in the question. This alternative, however, would maximally put at risk the coherence of the unfolding discourse. Therefore, it seems appropriate only for very minor mismatches between question and answer. This suggests that bueno and bien are mainly used for the repair of "mediumsize" coherence problems, which should be recognized but need not be explicitly addressed.

In the discussed examples, bien is not used as an adverb. That is, it is not used to positively evaluate the foregoing chunk of discourse, as the lexical meaning of the adverb would suggest. Now, what is the relation between the adverb bien and the discourse marker bien? In the following paragraphs, we shall sketch the diachronic evolution from adverb to discourse marker.

Originally used exclusively as an adverb, bien is found in discourse-marker function only from the late 18th / early 19th century onwards. An early unambiguous example in the CORDE corpus is (10).

(10) Bien as a discourse marker in 19th century Spanish (Larra, Doncel, 1834, CORDE)

Ferrus: $\quad$ Estoy harto pagado con el honor de servirte - dijo el astuto juglar.

'I'm abundantly paid with the honor to serve you, said the cunning minstrel.'

Don Enrique: Bien, dejemos lisonjas que tú no crees ni yo tampoco; toma esas monedas.

'Well, let's leave the flatteries that neither me nor you believe; take these coins.'

In this example, bien indicates that the second speaker - who apparently disapproves of the first speaker's proposal - wishes to put aside the entire topic while at the same time continuing a cooperative exchange.

The adverb bien 'well' is the source lexeme for a variety of linguistic expressions of different grammatical status. Many of these have in common that superficially positive evaluation is used for argumentation.

First, in earlier periods of Spanish, bien is used as a sentence-word. In this function it indicates the speaker's agreement with what has been said before (see (11)). This usage is already the outcome of a metonymic change which is based upon the inference that speakers normally evaluate favorably what they agree with. 
(11) Adverbial bien in 16th century Spanish (Rueda, Pasos, 1545, CORDE)

Coladilla: Escúchale. Dile, porque la sustancia no le haga mal, que le den algunas tajadas de calabaçate.

'Listen to her. Tell her that they must give her some slices of candied pumpkin, so that the substance does not hurt her so much.'

Monserrate: Bien, yo se lo diré.

'Good, I shall tell her so.'

Second, usage of adverbial bien may be part of concessive argumentations, where the speaker first concedes the validity of an argument but then goes on to put forward a much stronger counter-argument, as in (12).

(12)

Adverbial bien in concessive argumentation (Larra, Mostrador, 1831, CORDE) Borderó: [T]engo aquí una letra aceptada por vuestra señoría y endosada a mi favor, cuyo término ha expirado.

'I have here a promissory note signed by your grace and made out in my name, and which has expired.'

Bernardo: [...]. Bien, cierto; pero ¿qué tengo yo que ver con esto? Es verdad que yo he contraído la deuda, pero ¡qué! ¿Quiere usted que yo también la pague?

'Good, certainly; but what have I got to do with this? It's true that I contracted the debt obligation, but what! Do you want me to pay it, too?'

Even though the particular grammatical context bien ... pero 'good...but' is not the bridging context for the change from adverb to discourse marker (it is not even a construction), it is worthwhile examining in more detail its content, that is, the structure of concessive argumentation, since concessive argumentation illustrates how a marker of positive evaluation such as bien can be used to express mild disagreement. According to classical assumptions of argumentation theory (Anscombre and Ducrot 1977), the argumentational move $p$ BUT $q$ contains two arguments $p$ and $q$, where $p$ is an argument in favor of the conclusion $r$ and $q$ an argument against that conclusion. Uttering $p$ BUT $q$, the speaker presents both arguments $p$ and $q$ as valid. However, she marks $q$ (with its conclusion $-r$ ) as prevailing over $p$ (with its conclusion $r$ ). In many examples of 16th century Spanish, $p$ pero 'but' $q$ is preceded, as in (12), by bien, which introduces the weaker argument $p$. The role of bien in this context is to explicitly acknowledge the validity of $p$ without however canceling the effect of pero 'but', which makes $q$ the stronger one of both arguments. This explains why bien, in spite of being a marker of positive evaluation, is used to express disagreement. Note that in contexts such as (12), bien functions, moreover, as an anaphoric device. The speaker of bien $p$ pero $q$ refers to an argument of her interlocutor and ascribes it the value of $p$. Thus, concessive argumentation is an example of negotiation in discourse: by uttering bien p pero $q$ the speaker approves of an argument presented by her interlocutor, but only to ultimately refute it. 
This usage does not explain the evolution of bien into a discourse marker. It could at best explain the rise of bien as a concessive connective, as in si bien 'even though'. However, the argumentational move which paves bien's way towards the role of a discourse marker is quite similar to concessive argumentation.

A third diachronic outcome of argumentation with adverbial bien is the formula está bien / bien está 'it is good', which, again, is not the direct predecessor of bien as a discourse marker. How is bien está used? At first, by virtue of its original meaning, it expresses a positive evaluation of some state of affairs, which is typically uttered when the speaker is satisfied (13):

(13) Bien está as a marker of positive evaluation (San Vicente Ferrer, Serm., 1411, CORDE)

[...] aquellos niños que mueren, si mueren bautizados, bien está [...].

'Those children who die, if they die baptized, it's good.'

A typical reason for positive evaluation, in turn, is the completion of a state of affairs to the speaker's satisfaction. Thus, está bien / bien está 'it is good' expresses, as a result of a metonymic change, that the speaker considers an ongoing state of affairs as completed or even wants it to stop (see example 14).

(14) Bien está as a marker of completion (Anonymous, Relación, c. 1541, CORDE) Y trujeron ocho mil hombres de los pueblos y contáronlos y mostráronselos a 'And they brought 8000 men from the villages, counted them and showed them to'

Guzmán: "Basta; bien está."

'Enough, it is good.'

Está bien / bien está in the sense 'enough, it is good' can be an efficient rhetorical device in case the speaker wants to conceal her disagreement with some ongoing state of affairs to which she would like to put an end (15):

(15) Bien está as a rhetorical device for concealed disagreement (Cristobál de Castillejo, Diálogo de mujeres, 1500, DAVIES)

F: De ellas mana quanto bien el hombre gana, y ellas son la gloria de ello, la guarda, firmeza y sello de nuestra natura humana. 'They [women] are the fountain of whatever a good man earns and they are its best part [they are] the safeguard, the firmness and the seal of our human nature.'

A: Bien está, no habléys más de esso ya 'It's good [i.e. it's enough], please don't talk about this any more' 
In this sense, bien está is sometimes used as part of an argumentational move bien está $p$ (más bien) $q$ 'let's stop doing $p$ and (rather) start doing $q$ '. This can be seen in the following passage (16) taken from the Paso de Leno y Sulco, su amo, sobre el ratón, a 16th c. farce. Sulco, a rich cattle owner, has found his servant Leno sleeping in the haystack, but does not recognize him. Leno wants to make him believe that he is not Leno but some kind of exotic mouse imported from America. At some point of their absurd exchange, Sulco cuts off the conversation and orders his other servants to seize Leno and to tie him up - this brusque change of activity is introduced by bien está.

(16) Bien está announcing change of activity (Lope de Ruéda, Pasos, 1535, CORDE)

Sulco: Si tan grandes son como vos los ratones de vuestra tierra, los gatos que los caçaren, ¿de qué tamaño pueden ser?

'If the mice of your country are as big as you, what might be the size of the cats which hunt them?'

Leno: Señor, serán de quinze leguas de largo.

'Sir, they will be 15 miles long.'

Sulco: ¿Y de ancho?

'And how wide?'

Leno: Veynte y dos.

'Twenty-two.'

Sulco: ¿Cómo es possible ser más anchos que largos?

'How is it possible to be bigger in width than in length?'

Leno: Por que son hechos ancho por largo.

'Because they are made width by length [and not length by width].'

Sulco: ¿Y qué hazíades vos en mi pagiza?

'And what were you doing in my haystack?'

Leno: Señor, entréme huyendo de un cabo de guayta.

'Sir, I came in because I was fleeing from a sentinel officer.'

Sulco: Ora bien está. Átenle al brocal de aquel pozo y no le den de comer bocado hasta que venga quien le conozca.

'It's good / that's enough now. Tie him to this well and don't give him anything to eat until someone comes who knows him.'

Accordingly, apart from positive evaluation, i.e. its literal meaning, the formula bien está has developed two main contexts of use, namely implicit disagreement and change of activity.

Finally, bien as a discourse marker represents the same steps of diachronic change as bien está. Whereas bien está may refer to all kinds of human activity, bien as a discourse marker is specialized in the construction of discourse (see (10), repeated for convenience): 
(10) Bien as a discourse marker in 19th century Spanish (Larra, Doncel, 1834, CORDE)

Ferrus:

Estoy harto pagado con el honor de servirte - dijo el astuto juglar.

'I' $m$ abundantly paid with the honor to serve you, said the cunning minstrel.'

Don Enrique: Bien, dejemos lisonjas que tú no crees ni yo tampoco; toma esas monedas.

'Well, let's leave the flatteries that neither me nor you believe; take these coins.'

Like bien está as a marker of change of activity, bien as a discourse marker is the diachronic outcome of an argumentation relating two arguments. This explains why, as a discourse marker, it has a two-place structure, relating two chunks of discourse. More properties of the discourse marker bien can be explained from the diachronically underlying argumentation. Thus, like bien está in (16), bien as a discourse marker can express concealed disagreement (see (7), (12)), while at the same time signalling the speaker's willingness to pursue the discourse with a new topic. Thus, the diachronic path sketched here explains the synchronic intuition that bien serves to "negotiate" coherence.

The comparison between the development of bien está and bien brings to light another important property of discourse markers. Recall that bien está is not a discourse marker, but a formulaic device which serves to coordinate human activities of all kind. The purpose of bien as a discourse marker, however, is to coordinate the joint construal of discourse. Strictly speaking, discourse markers are just a subset of the routines humans have at their disposal for the coordination of their joint activities. Thus, it is not surprising that the diachronic evolution of a discourse marker should follow the same pathway as such a routine.

The same reasoning seems to apply to other discourse markers such as now as in (17), which serves to introduce a new topic into the discourse.

(17) Now as a discourse marker (Dickens: Sketches, 1836, OED)

Now this was bad enough, occurring as it did three times a week on the average, but this was not all.

Its source lexeme, the time adverbial now, can likewise be used to announce new referents or new events, introducing an abrupt change in the sequence of activities projected by the participants: ${ }^{5}$

(18) Temporal now coordinating unspecific human activities

And now back to our regularly scheduled program. (http://alisonknits.type pad.com/ alisonknits/2005/07/and_now_back_to.html)

5. For Sp. ahora 'now' see Silva-Corvalán (2001: 214-237), for Fr. maintenant 'now' see Saussure (to appear), for Old French or 'now', see Ollier (2000). 
Further cases in point are look and listen, which as discourse markers draw the attention of the hearer to the upcoming stretch of discourse (see (18), (20)). As free imperatives ((19), (21)) however, they can be used to make the listeners aware of all kinds of suitable linguistic or extra-linguistic stimuli (cf. Brinton 2001, Waltereit 2002):

(18) Look as a discourse marker (Sime, Hunters Point, 1973, OED)

Look, we don't have to sit here. We could go down to the beach.

(19) Look as a free imperative (Hurston, Mules \& Men, 1935, OED)

'Looka here, folkses,' Jim Presley exclaimed. 'Wese a half hour behind schedule.'

(20) Listen as a discourse marker (www.buffalobeast.com/80/shred.htm)

Umm, listen man; I need a little time here.

(21) Listen as a free imperative

Hey, listen to this!

Another case in point is French tiens 'look', which derives from the imperative form of tenir 'to hold'.

(22) Tiens as a discourse marker

Tiens, il pleut!

'Look, it rains!'

Our analysis explains, among other things, the observation that imperative verb forms are an important diachronic source of discourse markers (Dostie 2004). After all, imperatives are conventionally specialized in coordinating human activities of all kinds.

Conversation is a locally managed human activity (Sacks, Schegloff and Jefferson 1974). After every move, the participants have to decide anew upon the question: "What are we going to do next?" There is a constant requirement to negotiate and re-negotiate the following move. The successful outcome of this activity is discourse coherence. Discourse markers arise because lexemes are used for argumentational procedures which are helpful in those negotiations. Discourse markers of the type examined in this section are the routinized residue of negotiations about the next move.

\section{French bien - the rise of a modal particle}

We would now like to turn to French bien, a modal particle (see section 1). As shown in (23) and (24), bien is used in assertions and questions:

(23) French bien in assertions (Hansen 1998b: 111)

C'est bien la première fois que ça m'arrive!

'That $I S$ the first time that this happens to me !' 
(24) French bien in questions (= (4) above)

Vous avez bien reçu mon message?

'You did receive my message, didn't you?'

In (23), bien serves to reinforce the assertion. As has been shown by Hansen (1998b), bien is polyphonous. According to the theory of polyphony (Ducrot 1984; for a more recent comprehensive account see Iten 1999), some lexical items encode "controversies" between various "voices" (énonciateurs, E), each of which may be associated with a conversation participant, that is, the actual speaker herself (locuteur, L) and others (e.g. the hearer). In this model, an assertion with bien evokes two énonciateurs, E1 and E2. One of these, E2, who is associated with the speaker $\mathrm{L}$, denies the viewpoint of another énonciateur (E1).

\section{(25) Polyphonous bien}

a. [E1: Ce n'est pas la première fois que vous êtes en retard.] 'This is not the first time you are late!'

b. L (=E2) : C'est bien la première fois que je suis en retard. 'This IS the first time I am late!'

As can be seen in (25), the first énonciateur E1 evoked by bien always negates the propositional content of the utterance (25a), before E2, associated with the speaker's point of view (25b), denies E1's negation. Moreover, bien systematically implies that in this controversy E2 "wins out" over E1. In short, bien signals the denial on the part of the speaker of a denial on behalf of another discourse participant (typically, but not necessarily, the hearer). Negative assertions of the type (25a) may, but need not, occur in the preceding context of the utterance (25b). In the normal case, they are simply evoked or assumed. In this sense, assertions with bien are the mirror image of simple sentence negation (Hansen 1998b: 121), which also systematically implicates an opposite point of view (Givón 1979: 107) and is therefore another instance of polyphony (see Ducrot 1984: 214-223).

(26) Polyphonous sentence negation

a. (E1: C'est la première fois que je suis en retard.)

'This is the first time I am late.'

b. L (= E2): Ce n'est pas la première fois que vous êtes en retard.

'This is not the first time you are late!'

Givón (1995: 114) proposes a communicative re-definition of modality. According to him, categories of epistemic modality such as assertion, negation, irrealis assertion and presupposition not only make reference to the degree of subjective certainty on the part of the speaker. Above all, they anticipate the hearer's reaction to the validity of the speaker's utterance. In other words, they express the 
degree to which the speaker assumes her utterance to be (un)controversial in the eyes of the hearer. Given this interactional view of modality, our argumentation makes it clear what is "modal" about modal particles. The modal particle bien makes reference to strong counter-expectation on the part of the hearer, just as negation does. It is therefore an instantiation of communicative modality (see Hansen 1998b). It seems to us that this applies to modal particles in general. They crucially refer to participants' stance towards speech acts (Waltereit 2001). To that extent, modal particles are inherently polyphonous.

For the sake of completeness, it should be mentioned that bien is used not only in assertions, but also in questions:

(27) Bien in questions

C'est bien la première fois que vous êtes en retard?

'Is it really the first time you are late?'

In questions, bien is typically used by the speaker $(\mathrm{L}=\mathrm{E} 2)$ to further inquire about a previously raised issue. By virtue of its polyphonous structure, it evokes a foregoing assertion by the hearer (E1) to the effect that the corresponding proposition is true. This assertion can either be an actual utterance or it can be inferable from the context.

(28) a. [E1 : C'est la première fois que je suis en retard.]

'This is the first time I'm late.'

b. $\mathrm{L}=\mathrm{E} 2$ : C'est bien la première fois que vous êtes en retard?

'Is it really the first time you are late?'

Taken together, both uses of bien ((27) and (28)) show that modal particles are polyphonous items specialized for certain types of speech acts. In Ducrot's (1984) theory, polyphony is a conventional property of linguistic items. That is, it belongs to the level of langue, not of parole. In the following we will show that diachronically this property emerges from the conventionalization of effects in dialogic exchanges.

The modal particle bien, which has been in use since Old French, goes back to adverbial bien 'well'. Like in Modern French, the latter served to express a positive evaluation of a state of affairs:

(29) Bien 'well' as an adverb

Li mangiers fu bien atornez. (Chevalier de La Charrette 455, BFM)

'The meal was well prepared.'

We assume that the bridging contexts, where adverbial bien changed into the modal particle, were of the type (30). In these contexts, adverbial bien is used to argue against strong counter-expectation on the part of the hearer: 
(30) From adverb to modal particle: bridging context

Et mesires Pierres respondi: "Ba!“, fist il, "de n’avés vous oï comment Troies le grant fu destruite ne par quel tor ? - Ba ouil !", fisent li Blak et li Commain, "nous l'avons bien oï dire."

'And Mylord Pierre answered : 'Ba', he said, 'haven't you heard about how Troy the great was destroyed and in which way this happened ?' 'Of course', said Blak and Commain, 'we heard clearly / well about it.'

(Robert de Clari, La Conquête de Constantinople, CVI, 31, BFM)

From today's perspective, bien in (30) could either be the adverb 'well' or the modal particle. Construed as an adverb, it is used in (30) as part of a strategy of scalar argumentation. It serves to effectively counter a denial. In the dialogical context (30), L2 (Blak and Commain) refute the foregoing negation by L1 (mesires Pierre) ${ }^{6}$ Contrary to L1's claim that the proposition $p$ does not obtain, they contend that $p$ not only does hold, but that it even holds WELL. The argumentational move underlying the rise of the modal particle bien invokes a dialogical exchange of the kind given in (31).

(31) L1: $p$ is not the case.

L2: $p$ is WELL the case!

Example (30) is typical of Old French uses of bien insofar as the latter often appears together with verbs of knowledge (savoir 'to know') or verbs of perception (oir 'to hear', entendre 'to listen' and voir 'to see') expressing states of knowledge, as nous l'avons bien ö̈ dire 'we have well heard'. In these contexts, bien underscores the speaker's belief that his knowledge is valid despite an expectation to the contrary on the part of the hearer. Note that the hearer's stance does not necessarily need to be openly expressed. In example (32), adverbial bien is used to deny a counter-expectation which is only implicit. ${ }^{7}$ This in turn means that (31) can also appear in the less explicit form (31').

6. In (30) we are however not dealing with a plain negation but with a rhetorical question oriented towards a negative answer.

7. The context of (32) is the following. The king of Spain once promised his daughter to Jehan, son of the king of France, in return for the French king's support. Later on, however, he forgets his pledge and decides to engage his daughter to the king of England. Disguised as a rich merchant, Jehan joins the wedding party, where he puzzles his hosts (i.e. the king of Spain and his wife) with a strange riddle (which, of course, alludes to their original pledge). The passage in (32) renders the hosts' reaction when Jehan finally reveals his true identity. As a consequence of the novel's plot line, the common ground contains an expectation of the kind 'after all that happened, the king of Spain should know that his daughter is not worthy of getting married to the young king of France any more'. However, in (32) the king of Spain chooses to renew his original promise to the throne of France, which, against the backdrop of the common ground, could be interpreted as an impudent act. The half-sentence introduced by bien in (32) is intended to act against this impression. 
(32) Bien with presumed counter-expectation (Jehan de Paris, p. 84, BFM)

O trespuissant et noble roy, pour Dieu plaise vous nous pardonner nostre grant offence [...]. Et quant est de ma fille, bien sçay qu'elle n'est pas digne d'estre conjoincte avecq vous, mais dès maintenant je la vous livre [...].

'Oh almighty and noble king, for God's sake may it please you to forgive our great offence [...]. And as to my daughter, I do know well that she isn't worthy of getting married to you, but now I give her to you [...].'

(31') [L1: $p$ is not the case.]

L2: $p$ is WELL the case!

The scheme (31), (31') is an instance of scalar argumentation, invoking a scale as in (33). This means that the relation of bien and negation is not simply a syntagmatic one (use of bien prototypically follows negation contexts). What is more, bien and negation are also in paradigmatic relation, as they represent opposing endpoints on a scale of "validity of $p$ ". Thus bien 'well' as in (30) and (32) is a "contra"-negation syntagmatically and an "anti"-negation paradigmatically.
a. $p$ is not the case
b. $p$ is the case
c. $p$ is WELL the case!

Scalar argumentation means that (33c) $p$ is wELL the case is invoked as an argument in favour of the conclusion that (33b) $p$ is the case. This is done against strong counter-expectation, i.e. against the hearer's belief that (33a) $p$ is not the case is true. This argumentational move is given in (34). In (34) the speaker says that $p$ is WELL the case but he really means to say that $p$ REALLY is the case, despite strong expectation to the contrary.

(34) $p$ is WELL the case $\rightarrow p$ REALLY is the case (despite expectation to the contrary) "thing said" "thing meant"

Before the change from adverb to modal particle, the "thing meant" in (34), i.e. the conclusion that $p$ REALLY is the case, is a mere inference. The shift from bien 'well' to a modal particle takes place if this inference becomes conventionalized by frequent usage, and turns into the new meaning of bien. By the same token, the original effect of scalar argumentation will disappear altogether. This is shown in example (35). While in (30) and (32) bien is ambiguous between an interpretation as adverb or modal particle, we can be sure to deal with a modal particle in (35):

(35) Old French bien as a modal particle

Bien est de France (Ronc. p. 22, Littré)

'Indeed he is from France' 
The difference between bien in (30) and (32), on the one hand, and (35), on the other, is that (35) excludes a gradable interpretation. There are no degrees of "being from France". One is either from France or not. ${ }^{8}$ In (35) bien simply indicates that some state of affairs REALLY is the case despite expectations to the contrary.

If this analysis is correct, then we can describe the relationship between diachronic emergence of modal particles and their synchronic function. Diachronically, the modal particle bien arises from a dispute about the validity of the assertion of a proposition $p$. The synchronic residue of this is a polyphonous element which encodes speaker's assumptions about the hearer's attitude towards the validity of an assertion.

In Old French, bien appears much more rarely in questions than in assertive contexts. A bridging context is (36):

\section{(36) Old French bien in questions (Cent Nouvelles Nouvelles 68, BFM)}

Tenez, dit elle, fays je bien ce que vous plaist?

'Look, she said, do I do well [do I really do] what you like?'

The function is the same as in assertive contexts: what has been done WELL (against an expectation to the contrary) has REALLY been done. Bien in questions is inherently related to bien in assertions insofar as a question with bien could systematically be answered with an assertion containing bien. However, in actual Old French texts this is rather rare, as the normal item for replying to enquiries of this type is Old French certes 'sure', which is stronger than simple oui 'yes' (see (37)).

\section{(37) Old French bien and certes (Jehan de Paris 68, BFM)}

"Comment," dit la pucelle, "vous semble il bien que ung roy de France pouroit bien autant faire comme cestuy?" "Certes, ma doulce seur, je croy que ouy $[\ldots] "$

'What', said the girl, 'does it well seem to you that a king of France might well do as much as this one?' 'Sure, my dear sister, I think yes [...].'

The function of the modal particle bien in questions is the same as in assertive contexts. However, it seems that the change from adverbial bien 'well' to the modal particle occurred later in questions than in assertions (Schulze 1888: 87).

What can we learn from this change about the rise of modal particles? First, this change is metonymic (see Koch 1999; 2001). A form with the meaning 'well' is used to reinforce an assertive speech act in contexts of counter-expectation. Second, the modal particle emerges from a stereotyped argumentation which ori-

8. An anonymous reviewer objected that there might very well be degrees of "being from France". For example, someone born and having lived in France their whole life might claim to "be from France" to a higher degree than someone having lived there only a couple of years. While we agree that the arguments people can adduce in support of the claim of "being from France" may be found to be of varying strength, it seems obvious to us that the predicate to be from France itself is not gradable. 
ginally is dialogical in nature (see (31) and (31')). This explains the polyphonous semantics of modal particles.

\section{Conclusion}

As we have shown, both discourse markers and modal particles arise through metonymic semantic change. Furthermore, both emerge from dialogical argumentation patterns. The basic difference between both diachronic pathways lies in the nature of the respective argumentation. Discourse markers arise in contexts where speakers negotiate their further verbal interaction ("What are we going to do next?"). The argumentational patterns used here are the same as for the negotiation of non-verbal interactions. Modal particles, on the contrary, arise from stereotypical argumentational moves negotiating common ground ("What do I believe that you believe concerning the felicity of my speech act?").

The notion that the meaning of pragmatic markers may be specifically related to argumentation and the negotiation of viewpoints has been previously studied (e.g. Schwenter and Traugott 2000, Schwenter 2000). However, to our knowledge, is has not been sufficiently appreciated that the contemporary meaning of these items may arise as the by-product of argumentational routines for which their diachronic forerunners were actually used. Our model provides motivation for Traugott and Dasher's (2002: 187, 225) generalization that metatextual meanings tend to be recruited from propositional ones. In addition, it shows how and why different types of metatextual meaning arise in diachrony.

In past research, both the evolution of discourse markers and the emergence of modal particles have been analyzed within theoretical frameworks which aim at broad generalizations about semantic change. Thus, they have both been labeled as instances of grammaticalization (Diewald 2006, Silva Corvalán 2001, Autenrieth 2002, Wegener 2002), of pragmaticalization (Dostie 2004) or of subjectification (Traugott 1999, Traugott and Dasher 2002, Traugott and Brinton 2005, etc.). While the diachronic changes discussed in this paper do not contradict any of these assumptions, it seems clear to us that there are relevant differences which these labels fail to capture. Specifically, the latter are far too general to understand the respective synchronic function of both discourse markers and modal particles from a diachronic perspective.

\section{References}

Corpora

$\mathrm{BFM}=[\mathrm{bfm} . e n s-1 \mathrm{sh} . \mathrm{fr}]$

CORDE $=$ [corpus.rae.es/cordenet.html $]$

Corpus Oral $=[$ www. lllf.uam.es/ fmarcos/informes/ corpus/ corpulee.html $]$

DAVIES $=$ [www.corpusdelespanol.org $]$

Littré = Littré, Emile (1960-62). Dictionnaire de la langue française. Paris: Gallimard. $\mathrm{OED}=[$ dictionary.oed.com $]$ 
Anscombre, Jean-Claude; Ducrot, Oswald (1977). “Deux 'mais' en français?". Lingua 43: 23-40.

Autenrieth, Tanja (2002). Heterosemie und Grammatikalisierung bei Modalpartikeln. Eine synchrone und diachrone Studie anhand von eben, halt, ech(er)t, einfach, schlicht und glatt. Tübingen: Niemeyer.

Brémond, Capucine (2003). "Bon, moteur d'action, moteur du discours". Travaux Interdisciplinaires du Laboratoire Parole et Langage 22: 65-84.

Brinton, Laurel (2001). "From Matrix Clause to Pragmatic Marker: the History of LookForms”. Journal of Historical Pragmatics 2 (2): 177-199.

Diewald, Gabriele (2006). "Discourse particles and modal particles as grammatical elements". In: Fischer, Kerstin (ed.). Approaches to Discourse Particles. Oxford: Elsevier, pp. 403-426.

Dostie, Gaétane (2004). Pragmaticalisation et marqueurs discursifs. Analyse sémantique et traitement lexicographique. Bruxelles: De Boeck Duculot.

Ducrot, Oswald (1984). Le dire et le dit. Paris: Minuit.

Fuentes Rodríguez, Catalina (1998). La sintaxis de los relacionantes supraoracionales. Madrid: Arco. Second edition.

Garcés Gómez, María Pilar (1996). "Los marcadores discursivos en español”. In: Gil, Alberto; Schmitt, Christian. (eds). Kohäsion, Kohärenz, Modalität in Texten romanischer Sprachen. Bonn: Romanistischer Verlag, pp.126-147.

Givón, Talmy (1995). Functionalism and Grammar. Amsterdam/Philadelphia: John Benjamins.

Givón, Talmy (1979). On Understanding Grammar. New York: Academic Press.

Hansen, Maj-Britt Mosegaard (1995). "Marqueurs métadiscursifs en français parlé: l'exemple de bon et de ben". Le français moderne 63: 20-41.

Hansen, Maj-Britt Mosegaard (1998a). The function of discourse particles. A study with special reference to Spoken Standard French. Amsterdam: John Benjamins.

Hansen, Maj-Britt Mosegaard (1998b). "La grammaticalisation de l'interaction ou Pour une approche polysémique de l'adverbe bien”. Revue de Sémantique et Pragmatique 4, 111-138.

Iten, Corinne (1999). "The relevance of argumentation theory". UCL Working Papers in Linguistics 11: 41-81.

Koch, Peter (1999). "Frame and contiguity: On the cognitive bases of metonymy and certain types of word formation". In: Radden, Günter; Panther, Klaus-Uwe (eds.). Metonymy in language and thought. Amsterdam/Philadelphia: John Benjamins, pp. 139-167.

Koch, Peter (2001). "Metonymy: unity in diversity". Journal of Historical Pragmatics 2: 201-244.

Martín Zorraquino, María Antonia; Portolés, José (1999). "Los marcadores del discurso". In: Bosque, Ignacio; Demonte, Violeta (eds.). Gramática descriptiva de la lengua española, pp. 4051-4213.

Ollier, Marie-Louise (2000). "Linguistique de l'énonciation d'une langue morte. Analyse de Or avez vos folie dite". In: Ollier, Marie-Louise: La forme du sens. Textes narratifs des XIIe et XIIIe siècles. Études littéraires et linguistiques. Orléans: Éditions Paradigme, pp. 433-459.

Sacks, Harvey; Schegloff, Emanuel A.; Jefferson, Gail (1974). "A simplest systematics for the organization of turn-taking in conversation". Language 50, 696-735. 
Saussure, Louis de (to appear). "Maintenant: présent cognitif et enrichissement pragmatique". Cahiers Chronos. Amsterdam: Rodopi.

Schulze, Alfred (1888). Der altfranzösische direkte Fragesatz. Ein Beitrag zur Syntax des Französischen. Leipzig: Hirzel.

Schwenter, Scott A. (2000). "Viewpoints and polysemy: Linking adversative and causal meanings of discourse markers". In: Kortmann, Bernd; Couper-Kuhlen, Elisabeth (eds.). Cause-Condition-Contrast-Concession. Berlin: Mouton de Gruyter, pp. 257-81.

Schwenter, Scott A.; Traugott, Elizabeth Closs (2000). "Invoking scalarity: The development of 'in fact'. Journal of Historical Pragmatics 1: 7-25.

Serrano, María José (1999). "Bueno como marcador discursivo de inicio de turno y contraposición: estudio sociolingüístico". International Journal of the Sociology of Language 140:115-133.

Silva-Corvalán, Carmen (2001). Sociolingüística y pragmática del español. Georgetown/Washington, DC: Georgetown University Press.

Traugott, Elizabeth Closs (1999). "The role of pragmatics in a theory of semantic change". In: Verschueren, Jef (ed.). Pragmatics in 1998: Selected Papers from the 6th International Pragmatics Conference, Vol. 2. Antwerp: International Pragmatics Association, 93-102.

Traugott, Elizabeth Closs; Brinton, Laurel J. (2005). Lexicalization and language change. Cambridge: Cambridge University Press.

Traugott, Elizabeth Closs; Dasher, Richard B. (2002). Regularity in semantic change. Cambridge: Cambridge University Press.

Waltereit, Richard (2001). "Modal particles and their functional equivalents: a speechact-theoretic approach". Journal of Pragmatics 33: 1391-1417.

Waltereit, Richard (2002). "Imperatives, interruption in conversation and the rise of discourse particles: A study of Italian guarda". Linguistics 40: 987-1010.

Waltereit, Richard (2006). "Comparer la polysémie des marqueurs discursifs". In: Drescher, Martina; Frank-Job, Barbara (eds.). Les marqueurs discursifs dans les langues romanes. Approches théoriques et méthodologiques. Frankfurt: Lang, pp.141-151.

Wegener, Heide (2002). "The evolution of the German modal particle denn". In: Wischer, Ilse; Diewald, Gabriele (eds.). New Reflections on Grammaticalization. Amsterdam: John Benjamins, pp. 379-394. 